OPEN ACCESS

Edited by:

Luca Rastrelli,

University of Salerno, Italy

Reviewed by:

Zuhaib Bhat,

Lincoln University, New Zealand

Marta Laranjo,

University of Evora, Portugal

${ }^{*}$ Correspondence:

Mihai Cenariu

mihai.cenariu@usamvcluj.ro

Specialty section

This article was submitted to

Nutrition and Food Science

Technology,

a section of the journal

Frontiers in Nutrition

Received: 29 July 2021

Accepted: 07 September 2021

Published: 04 October 2021

Citation:

Munteanu C, Mireșan V, Răducu C,

Ihuț $A$, Uiuiu P, Pop D, Neacşu A, Cenariu M and Groza I (2021) Can

Cultured Meat Be an Alternative to

Farm Animal Production for a Sustainable and Healthier Lifestyle?

Front. Nutr. 8:749298

doi: 10.3389/fnut.2021.749298

\section{Can Cultured Meat Be an Alternative to Farm Animal Production for a Sustainable and Healthier Lifestyle?}

\author{
Camelia Munteanu ${ }^{1}$, Vioara Mireşan ${ }^{2}$, Camelia Răducu ${ }^{3}$, Andrada Ihuț ${ }^{3}$, Paul Uiuiu ${ }^{2}$, \\ Daria Pop ${ }^{4}$, Alexandra Neacşu ${ }^{5}$, Mihai Cenariu ${ }^{6 *}$ and loan Groza ${ }^{6}$ \\ 1 Department of Plant Culture, University of Agricultural Sciences and Veterinary Medicine Cluj-Napoca, Cluj-Napoca, \\ Romania, ${ }^{2}$ Department of Fundamental Sciences, University of Agricultural Sciences and Veterinary Medicine Cluj-Napoca, \\ Cluj-Napoca, Romania, ${ }^{3}$ Department of Technological Sciences, University of Agricultural Sciences and Veterinary Medicine \\ Cluj-Napoca, Cluj-Napoca, Romania, ${ }^{4}$ Clinic of Obstetrics and Gynecology II "Dominic Stanca," University of Medicine and \\ Pharmacy "Iuliu Hatieganu" Cluj-Napoca, Cluj-Napoca, Romania, ${ }^{5}$ Department of Chemical Engineering, Babeș-Bolyai \\ University, Cluj-Napoca, Romania, ${ }^{6}$ Department of Animal Reproduction and Reproductive Pathology, University of \\ Agricultural Sciences and Veterinary Medicine Cluj-Napoca, Cluj-Napoca, Romania
}

Producing animal proteins requires large areas of agricultural land and is a major source of greenhouse gases. Cellular agriculture, especially cultured meat, could be a potential alternative for the environment and human health. It enables meat and other agricultural products to be grown from cells in a bioreactor without being taken from farm animals. This paper aims at an interdisciplinary review of literature focusing on potential benefits and risks associated with cultured meat. To achieve this goal, several international databases and governmental projects were thoroughly analyzed using keywords and phrases with specialty terms. This is a growing scientific domain, which has generated a series of debates regarding its potential effects. On the one hand the potential of beneficial effects is the reduction of agricultural land usage, pollution and the improvement of human health. Other authors question if cultured meat could be a sustainable alternative for reducing gas emissions. Interestingly, the energy used for cultured meat could be higher, due to the replacement of some biological functions, by technological processes. For potential effects to turn into results, a realistic understanding of the technology involved and more experimental studies are required.

Keywords: cultured meat, health, greenhouse gases, bioreactor, animal welfare

\section{INTRODUCTION}

According to the United Nations (1), the world population has grown over the past 10 years, reaching nearly 7.6 billion people in 2017, while it is estimated that by 2050 it will reach 9.8 billion people. Population growth, urbanization and income growth in developing countries along with the high importance of animal products in the majority of the global population's diet (2) have led to a search for sustainable alternatives to conventional products with less negative impact on the environment and, conversely, even on health.

Livestock breeding requires a significant amount of natural resources and plays a big role in global greenhouse gas emissions (3). Also, conventional meat production has other side effects, such as a decrease in nutritional value, foodborne illnesses and depletion of environmental resources, along with the suffering and slaughtering of animals (4). Post (5), believes that these alternatives 
should generally be based on sustainability, the reduction of environmental impact and increasing animal welfare. In addition, a 2010 UN Environment Program report showed that a significant reduction of agriculture's environmental impact would only be possible with a substantial change in the global diet $(6,7)$. From this perspective, cultured meat can be an alternative. According to Mattick (8), cellular agriculture is a revolutionary technology that makes it possible for both meat and other agricultural products to be grown from cells in a bioreactor without being taken from farm animals (Figure 1) (9).

This paper aims at an interdisciplinary review of literature focusing on the potential benefits and risks associated with cultured meat analyzed from both environmental and medical points of view. Interventional studies involving animals or humans, and other studies that require ethical approval, must list the authority that provided approval and the corresponding ethical approval code.

To achieve this goal, several international databases and government projects were thoroughly analyzed using keywords and phrases containing specialty terms such as "cellular agriculture," "cultured meat," "in vitro meat," "health," "gas emissions."

In this paper, we have gathered and presented the results of several studies, reviews, reports and government projects. These studies cover a long period of time from 2000 to 2021. Thus, this review will emphasize on several aspects of cultured meat production, including the following issues: bioreactors (comparative analysis of the existing equipment and an original proposal), current status analysis of cultured meat bioprocessing, as well as advantages and disadvantages of cultured meat consumption.

\section{BIOREACTORS USED FOR CULTURED MEAT PRODUCTION}

Bioreactors are devices in which biological and/or biochemical processes develop under the precise control of environmental and operating conditions $(\mathrm{pH}$, temperature, pressure, nutrient supply and waste disposal) (10). It all stems from the form and typology of the final product, as for example, processed meat vs. completely carved meat, or a source of dry protein in a powder form vs. a wet cell biomass. All this has a great impact on the type of bioreactor to be chosen. The purpose of a bioreactor is to generate an adequate controlled environment for the in vitro management of mammalian cells (11). The two sequential phases of the cell culture process, namely proliferation and differentiation form the basis of the bioprocess design, because the cultured cells are the desired final products. The design is iterative, as the choices must be made together with the calculations of mass balances, energy balances and methods of heat supply/disposal, including the integration of heat to save energy. An example of an upstream and downstream project iteration is used for recycling in order to save water and the size of waste recovery units to use waste products. All this is dependent on the flow rate of the bioreactor effluent. Along with the bioreactor for proliferation and differentiation, the upstream process probably includes units such as environmental storage tanks, environmental heat exchanger and a means of maintaining isothermal conditions (constant temperature) in the bioreactor. All these characteristics are presented in Table $\mathbf{1 .}$

In this respect, high reproducibility, control and automation of bioreactors for specific experimental bioprocesses are key to their transfer toward large-scale applications. In general, bioreactors are used in industrial fermentation processing, wastewater treatment, food processing and the production of recombinant pharmaceuticals and proteins.

As a field, tissue engineering has been defined as the application of engineering principles and methods in life sciences to the development of biological substituents to restore, maintain or improve tissue function (12). Normally, the most typical approach is to make $3 \mathrm{D}$ tissue structures generated by associating cells (autologous or allogeneic) with porous scaffolds, which provide the pattern for tissue development. They subsequently degrade or are reabsorbed at defined speeds.

The in vitro culture of $3 \mathrm{D}$ cell-scaffolds is performed under conditions that support efficient cell nutrition, possibly combined with the application of mechanical forces for direct cellular activity and with phenotype. It is thus a paramount step for the development of functional grafts in the treatment of lost or damaged parts of the body (13). Moreover, the designed tissues could provide reliable model systems, which allow a much better understanding of the structure-function relationships both under normal and pathological conditions. The result of these processes may have commercial applications in molecular therapy (e.g., drug screening) (14). In addition, the generation of $3 \mathrm{D}$ vivo tissues in addition to the development of new biological models (15) requires new technical challenges, due to the particular physico-chemical requirements of large cell masses. Cellular seeding of scaffolds - i.e., the dissemination of isolated cells in a scaffold - is the first step in establishing a 3D culture and could play a crucial role in determining the progression of tissue formation (16).

Indeed, high-density scaffold cell culture has been associated with improved tissue formation in $3 \mathrm{D}$ constructions, which includes higher rates of cartilage matrix production (17), increased bone mineralization (18), and improved heart tissue structure (19). Thus, the engineering of autologous grafts for clinical applications involves the use of high initial cell densities. However, while limiting the size of the biopsy and/or the degree of cell expansion, it is required that the cells be seeded as efficiently as possible. Moreover, the initial distribution of cells in the scaffold after seeding was related to the distribution of tissue subsequently formed in the designed constructs (20), suggesting that even cell seeding could establish the basis for even tissue generation.

The most efficient and even results were obtained when the cells were seeded in bioreactors equipped with stirring flask (21). Mixing the diluted cell suspension around the stationary scaffolds suspended from the mouth of the flask transports the cells into the scaffold by convection. However, most likely due to inefficient cell convection in the inner scaffold region, seeding in stirring flask bioreactors may also have low seeding efficiency $(19,20)$. In 


\section{Production stages of Clean meat}

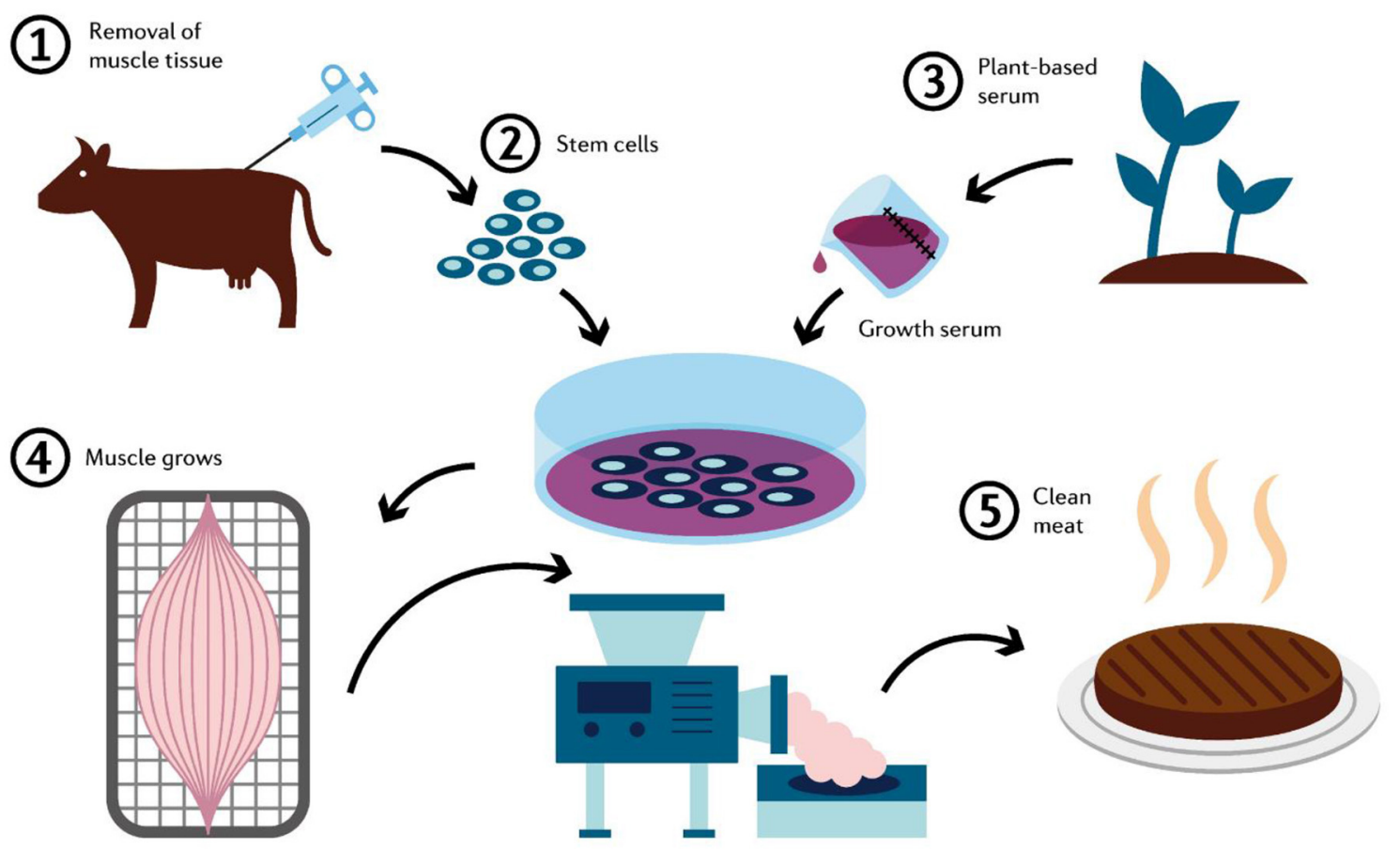

FIGURE 1 | Culture meat cycle. Source: (9). 1- non-invasive uptake of stem cells from cows; 2 and 3 represent the steps in which cell culture takes place in a cultured environment to grow and divide; 4 - differentiation of cells tissues that are identical to the one harvested from the animal; 5 -meat processing in order to reach the consumer directly.

terms of cell distribution, it may become uneven $(21,22)$, with a higher density of cells lining the surface of the scaffold (23).

Applying the principle of convective transport for scaffold seeding, the flow of a cell suspension directly through 3D scaffold pores using a multi-pass filter seeding technique produced more evenly distributed cell scaffolds compared to static seeding (24). When direct infusion was incorporated into an automatic bioreactor for seeding 3D scaffolds, higher seeding efficiencies and more uniform cell distributions were obtained compared to static seeding or the stirring flask bioreactor (22). By using this simple concept, a variety of scaffolds can be seeded efficiently and reproducibly in an automatic and controlled process.

Interestingly, infusion seeding can be easily integrated into an infusion bioreactor system (Table 2) capable of performing both scaffold seeding and subsequent culture of the preparation. These seeding and culturing bioreactors were designed for vascular graft engineering (32) and were used in cartilage (33) and heart tissue engineering (34) and in maintaining hepatocyte function in $3 \mathrm{D}$ scaffolds (20).

These systems not only simplify the engineering process, but also reduce the safety risks associated with the handling and transfer of biological preparations between separate bioreactors.
The most successful method is to use bioreactors that perfuse the environment through or around the semi-permeable hollow fibers of the scaffold, because the function of cells with an intense metabolism is maintained. This can be done by increasing the transport of nutrients and oxygen to the culture preparation. This concept has been extended to cultured tissues by perfusing the culture medium directly through the pores of the $3 \mathrm{D}$ scaffold with initial cells, which results in the reduction of mass transfer limitations. Direct perfusion bioreactors have been shown to improve: growth, differentiation, and deposition of mineralized matrix by bone cells (35), proliferation of human oral keratinocytes (36), rates of albumin synthesis by hepatocytes (20), the expression of specific cardiac markers by cardiomyocytes (37). Therefore, when direct perfusion is incorporated into a bioreactor, it substantially improves the survival, growth and function of all cells. It seems that even in this case, depending on the results of several studies for 3D cultures of chondrocytes, things are not perfect, because the effects of direct perfusion can be very dependent on the average flow and the stage of maturation of preparations (33). Therefore, the optimization of an infusion bioreactor for 3D tissue engineering must strike a careful balance between mass transfer of nutrients and residual 
TABLE 1 | The efficient characteristics of bioprocess in bioreactors.

\begin{tabular}{|c|c|}
\hline Bioprocess: needs & $\begin{array}{l}\text { Product formulation, upstream units, downstream units, pipelines, pumps, valves, heat exchangers, storage vessels, instrumentation } \\
\text { e.g., temperature and pressure sensors, flowmeters, control system, capital cost-infrastructure, units, raw material sourcing, } \\
\text { packaging, labeling }\end{array}$ \\
\hline Cells & $\begin{array}{l}\text { Type of cells used for culture } \\
\text { Myoblast, myosatellite, iPSCs, etc. } \\
\text { Primary-isolation, purification, verification } \\
\text { Immortalized-cell line development Specific properties of cells } \\
\text { Cell specific growth rate } \\
\text { Method of inducing differentiation } \\
\text { Anchorage dependent or non-adherent } \\
\text { Metabolic stoichiometry } \\
\text { Degree of differentiation required } \\
\text { Size, mass (dry or/and wet), phenotype }\end{array}$ \\
\hline Medium & $\begin{array}{l}\text { Concentration and composition of essential nutrients, growth factors, vitamins. } \\
\text { Rates of substrate consumption } \\
\text { By-product production rates } \\
\text { Source and variability e.g., serum, serum-free, chemically defined } \\
\text { pH, osmolality, compound degradation } \\
\text { Purchasing form: pre-formulated, powder, concentrates } \\
\text { Storage requirements e.g., refrigeration impacts energy requirements } \\
\text { In-house formulation e.g., culture grade water required and sterilization }\end{array}$ \\
\hline Scaffolds & $\begin{array}{l}\text { Cytocompatible-non-toxic, supports cell attachment, viability and proliferation/differentiation } \\
\text { Cell dissociation method for passaging and/or end-of-batch processing (with or without porous) } \\
\text { Material (natural or synthetic) } \\
\text { Surface area to volume ratio } \\
\text { Edible, biodegradable or non-degradable } \\
\text { Final form e.g., microcarrier, hydrogel } \\
\text { Source of final scaffold form: commercial supplier or in-house fabrication } \\
\text { Mechanical and surface properties e.g., stiffness, striations } \\
\text { Raw material source: sustainable, animal derived, etc. }\end{array}$ \\
\hline Bioreactor & $\begin{array}{l}\text { Type e.g., agitated with ball or perfusion (classically or direct) } \\
\text { Mode of operation: batch, fed-batch, continuous (perfusion) } \\
\text { Passaging method \& requirements } \\
\text { Inoculum method \& density } \\
\text { Homogenous environment - mixing, shear stress, sparging, heat supply/removal } \\
\text { Monitoring \& instrumentation: temperature, pH, dissolved oxygen, carbon dioxide, nutrients and byproducts, osmolality } \\
\text { Cleaning and sterilization } \\
\text { Proliferation/differentiation phase } \\
\text { Oxygen supply } \\
\text { Scale-up }\end{array}$ \\
\hline The formulation of final product & $\begin{array}{l}\text { Cell dissociation (if non-edible) or cell scaffold complex extraction } \\
\text { Cell/tissue harvesting } \\
\text { Product formulation } \\
\text { Product unit size } \\
\text { Packaging and labeling }\end{array}$ \\
\hline Waste treatment and recycling & $\begin{array}{l}\text { Waste identification e.g., by-products such as ammonia and lactate } \\
\text { Waste separation e.g., electrodialysis, filtration } \\
\text { By-product recovery } \\
\text { Re-usable media recovery, recycle, additional substrate supplementation } \\
\text { Waste valorization/up-scaling e.g., use as feedstock for alternative process/industry } \\
\text { Energy and cost }\end{array}$ \\
\hline
\end{tabular}

products to and from cells, retention of newly synthesized extracellular matrix components within the construct, and shear stresses induced by fluid in the scaffold pores. Furthermore, the mechanism for the application of mechanical forces to $3 \mathrm{D}$ constructs could be much improved, beyond the conventional approach of improving cell differentiation and/or deposition of the extracellular matrix in the prepared tissues.

They can serve as in vitro models to study the pathophysiological effects of physical forces on developing tissues. It could also predict the responses of newly formed tissue to physiological forces during surgical implantation. Moreover, bioreactors together with the mechanical response of the preparation could help to define the best time for the processed tissues to have sufficient mechanical integrity and a normal biological reaction in order for it to be implanted (Figures 2-5) (38).

Next, this review will present the bioprocesses of cultured meat, by analyzing the current status of this procedure and discussing the possibilities of improvement. 
TABLE 2 | Bioreactors.

\begin{tabular}{|c|c|c|}
\hline Type of bioreactors & Advantages & Disadvantages \\
\hline Stirring flask bioreactors (Figure 2) & $\begin{array}{l}\text { - The most efficient and even results obtained } \\
\text { - Cells distributed more evenly compared to static } \\
\text { seeding (26) }\end{array}$ & $\begin{array}{l}\text { - Low seeding efficiency in the inner region of the scaffolding } \\
\text { - The distribution of cells may become uneven, with a higher } \\
\text { density of cells lining the surface of the scaffold }\end{array}$ \\
\hline Perfusion bioreactors (Figure 3) & $\begin{array}{l}\text { - Simplifies the engineering process, and reduces the safety } \\
\text { risks associated with the handling and transfer of biological } \\
\text { preparations between separate bioreactors. } \\
\text { - Seeding the scaffolding, as well as the subsequent } \\
\text { cultivation of the preparation } \\
\text { - Vascular graft engineering (28) } \\
\text { - Cartilage and heart tissue engineering and maintaining the } \\
\text { function of hepatocytes in 3D scaffolding. } \\
\text { - Simplifies the engineering process, and reduces the safety } \\
\text { risks associated with the handling and transfer of biological } \\
\text { preparations between separate bioreactors }\end{array}$ & \\
\hline $\begin{array}{l}\text { Direct perfusion bioreactors } \\
\text { (Figure 4B) }\end{array}$ & $\begin{array}{l}\text { - Improve: growth, differentiation and deposition of the } \\
\text { mineralized matrix by bone cells (30), } \\
\text { - proliferation of human oral keratinocytes, } \\
\text { - rates of albumin synthesis by hepatocytes, } \\
\text { - expression of specific cardiac markers by cardiomyocytes. } \\
\text { - Substantially improves the survival, growth and function of } \\
\text { all cells. }\end{array}$ & $\begin{array}{l}\text { - The effects of direct infusion may be highly dependent on } \\
\text { the average flow rate and the stage of maturation of the } \\
\text { preparations (31) } \\
\text { - The mechanism of applying mechanical forces to 3D } \\
\text { constructions could be much improved }\end{array}$ \\
\hline
\end{tabular}

\section{BIOPROCESS OF CULTURED MEAT}

Nowadays, cultured meat can be obtained using several methods which include cell cultivation from muscle biopsies, tissue engineering as well as organ printing and nanotechnology (39, 40). Currently, these methods can only be applied at a small scale and are not yet adequate for large scale and commercial production $(41,42)$.

Certainly, a further question arises: how can the whole process be transferred onto a large, industrial scale? Furthermore, whether this process will not have negative effects on human health in the short and long term? These questions are closely related to the fact that growth hormone promoters are banned in agricultural systems for conventional meat production in the European Union (unlike other parts of the world).

Nevertheless, it is a long way to the real muscle, which consists of orderly fibers, blood vessels, nerves, connective tissue and fat cells (43). This is why different start-ups working in this field have developed different strategies: some of them work with stem cells or muscle cells to reproduce disorganized muscle fibers, which is the simplest approach, while others try to reproduce thin slices of muscle (i.e., muscle fibers and other cell types quite well-nested together).

However, producing a thick piece of meat similar to a real steak is still a dream, due to the need to infuse oxygen inside the meat to mimic the diffusion of oxygen as it appears in real tissue (44). Everything starts from stem cells that are collected in a non-invasive way from an animal. Subsequently, the cells are grown in a controlled environment, which provides favorable conditions for growth and division. Finally, it distinguishes itself into a tissue that is identical to the meat harvested from the animals (8). Two types of stem cells could be used: embryonic or myosatellite skeletal muscle cells.
When it comes to the cultivation of cultured meat, a typical material used for scaffolding is represented by the collagen spheres that transform stem cells into myotubes (45).

Stem cell technology for in vitro meat production was explored many years ago, but has not been industrialized yet. Nevertheless, there are some authors who believe that the development of stem cell and tissue engineering ensures the possibility of large-scale cultured meat production $(46,47)$. Cultivated meat requires a large number of differentiated muscle cells to form tissues. As it was pointed out before, maintaining healthy cells is achieved by providing fresh nutrients, while increasing the number of cells by maintaining constant cell division (48).

However, most cells have a limited ability to divide, known as the Hayflick limit, which restricts muscle tissue cultures in a large-scale laboratory. In this regard, effective ways have been developed to increase proliferation, including increasing the regenerative potential of stem cells. It is known that the Hayflick limit is determined by the length of the telomeres, which is a repeated sequence at the end of the guanine-rich chromosomes. Telomeres shorten with each replication, affecting the cell's ability to proliferate. Telomerase, which prolongs telomeres, is found in anti-aging cell lines. Therefore, regulating the expression or exogenous addition of telomerase can effectively enhance the potential for cell regeneration, which is conducive to large-scale, stable, and rapid proliferation of animal cells (49).

In addition, another major challenge is the need to support high cell densities to match those in native tissue (108-109 cells $/ \mathrm{ml}$ ) (50). However, most research on cultured muscle tissue has been performed at relatively low cell densities $(107$ cells $/ \mathrm{ml})$ (51). Adapting to the need for high encapsulated cell density may require adapting scaffolding to ensure manufacturing feasibility and optimize the cellular microenvironment. Moreover, muscles 
are made up of muscle fibers with different metabolic rates. The question is how is it possible to maintain this difference in vitro to copy the native tissue as accurately as possible? Alternative approaches to maximize protein content in cultured meat prototypes include the use of edible, protein, or biodegradable scaffolds that are replaced by cells and their ECM proteins secreted during culture (52).

Historically, the NASA institute played an important role in the history of clean meat technology: it pioneered the production of muscle protein substitutes for astronauts and space station inhabitants. Over time, different approaches to potential in vitro meat production began to emerge (4). All this culminated with the creation of the first meat burger in 2013, cultivated by Professor Mark Post from the University of Maastricht, at a conference in London 2013 (53). Collaboration projects have started to appear in recent years among companies such as Mark Post's Mosa Meat (Netherlands), Aleph Farms (Israel) and Cellular Agriculture Ltd (United Kingdom) and some prestigious universities, which carry out biomedical academic research programs on this topic (54). Therefore, most of the research in the field is conducted within start-up companies, which can be selective regarding the information provided to the public about the technological process. Thus, it is quite difficult to know precisely what each company does (55). In parallel, meat substitutes were created and developed. They are entirely plantbased. Most products contain soy, milk protein, whey protein or mushrooms, while also meeting all criteria for efficient low carbon footprint protein production (56). It must be pointed out that there is also cellular agriculture based on fermentation and it is different from the one based on tissue engineering, as it does not use tissues from living animals. Genetically modified bacteria, algae or yeasts were used to obtain fermentation-based products by adding recombinant DNA to produce organic molecules (Figure 6) (57).

As such, obtaining some known animal products (gelatin, casein and collagen) is based on the use of these molecules (Clara Foods - egg white, Perfect Day - formerly Muufri milk). This type of agriculture is different from cellular tissue engineering because the products related to this technology can be traded in a shorter period and are based on the usual industrial biotechnology. Also, the technology used in cellular tissue engineering agriculture has not been proven efficient for large-scale production (58).

Most of the time, people have been skeptical and even dismissive when confronted with advanced technologies, especially when it comes to food. Therefore, this topic has generated a series of debates regarding the possible beneficial effects and the risks for the environment and health. According to Hocquette et al. (58), in vitro meat can reduce the carbon footprint and meet all the nutritional needs and desires of the consumers. Some researchers even suggest that cell agriculture is going to have beneficial effects, starting from increasing animal welfare to improving human health (10). Van der Weele and Driessen (59) claim that cultured meat can be a healthier alternative because it is safer to control the bacteria and viruses in cell cultures than in animals, while they also claim that cultured meat could be enriched with healthy compounds.

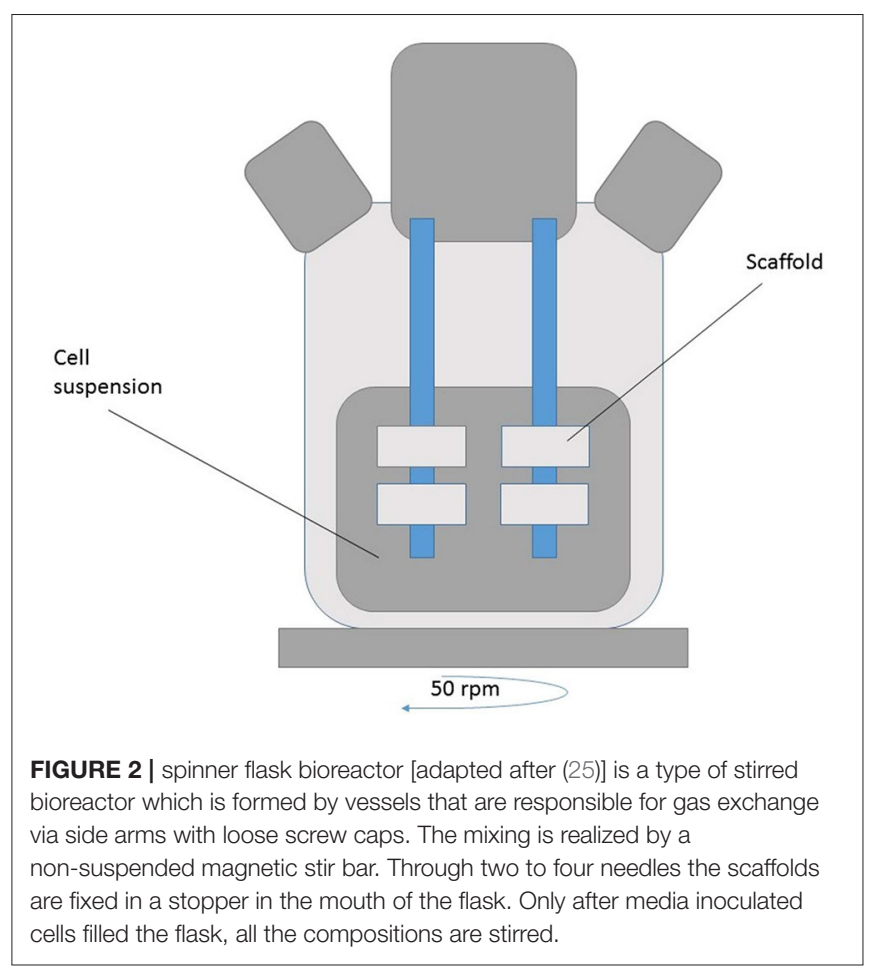

There are also supporters of "non-animal products," that ask themselves what meat, milk, eggs and other products obtained from cellular agriculture are (6). Interestingly, Mattick (8) has another vision on this technology and shows that when it comes to the production of pork and poultry, greenhouse gas emissions may be twice as high as those produced using conventional techniques, because the consumption of energy associated with in vitro meat is much higher.

In addition to bioreactors, stem cells and medium, artificial scaffolds (Figure 7) (60) and scaffold-based tissue engineering strategies are needed to obtain cultured meat. The natural question is "what are artificial scaffolds?" They represent the equivalent of the extracellular matrix. In vitro meat production for processed meat products requires the large-scale cultivation of stem cells in large bioreactors. Stem cells and skeletal muscle cells need both a solid surface for cultivation and a large surface to generate the wanted amount of muscle cells. They resemble the architecture of the native tissue and provide a medium that allows the growth of culture volumes (45). There are 2 major types of bioreactors used in this industry: reusable ones (stainless steel) and single-use ones. They are chosen based on the specific process that is going to take place.

Cultured meat production using the above-mentioned bioprocesses has obvious advantages regarding the impacts on environment, human health, land usage, water pollution and animal welfare. In the same time, it has some disadvantages referring to its quality, flavor and content. The following sections will show the benefits and drawbacks of cultured meat production and consumption. 


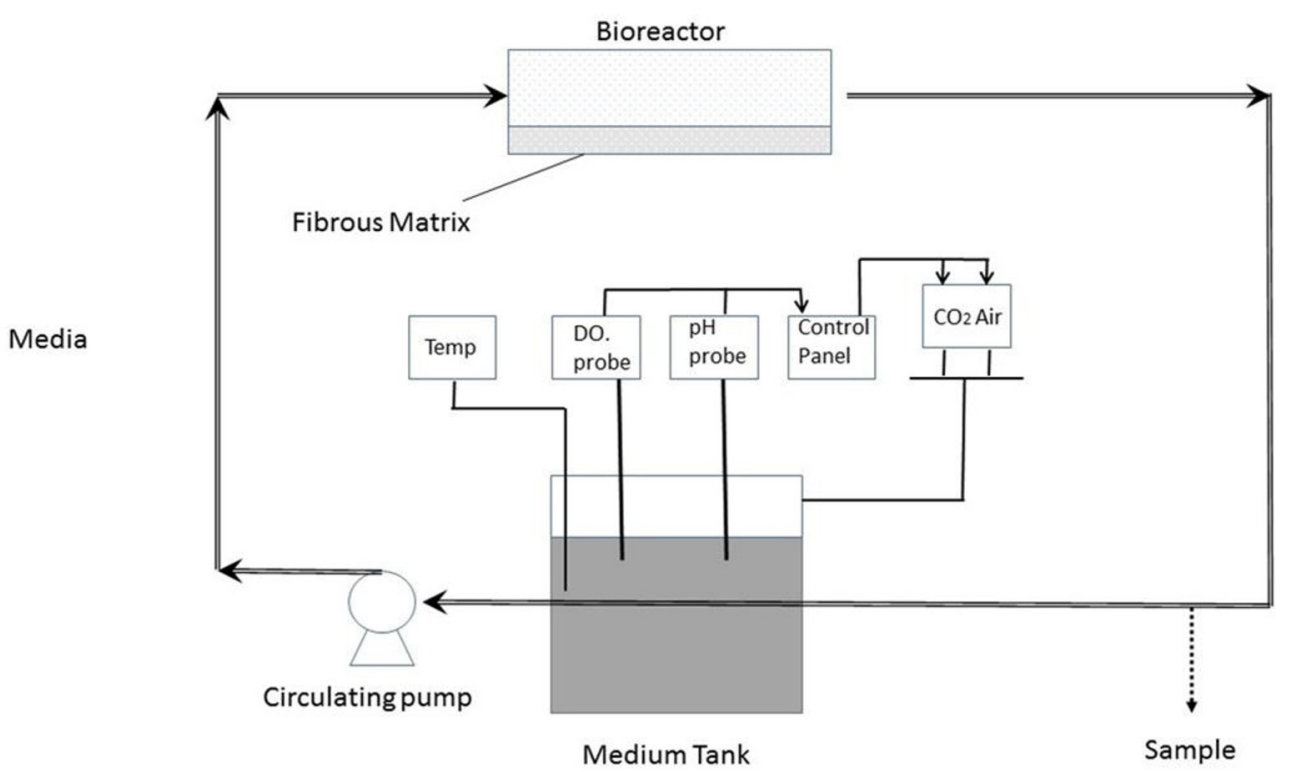

FIGURE 3 | Perfusion bioreactor [adapted after (27)] - The cells are seeded into PET fibrous matrix and incubated for 1 day in a CO 2 incubator; scaffolds have usually adherent cells; In the bioreactor chamber, the cells are placed horizontally; The culture medium is pumped in a parallel direction to cell-matrix through the chamber at a low flow rate; The temperature usually is at $37 \mathrm{C}$; The $\mathrm{pH}$ is maintained at a physiological range of 7.2-7.4.
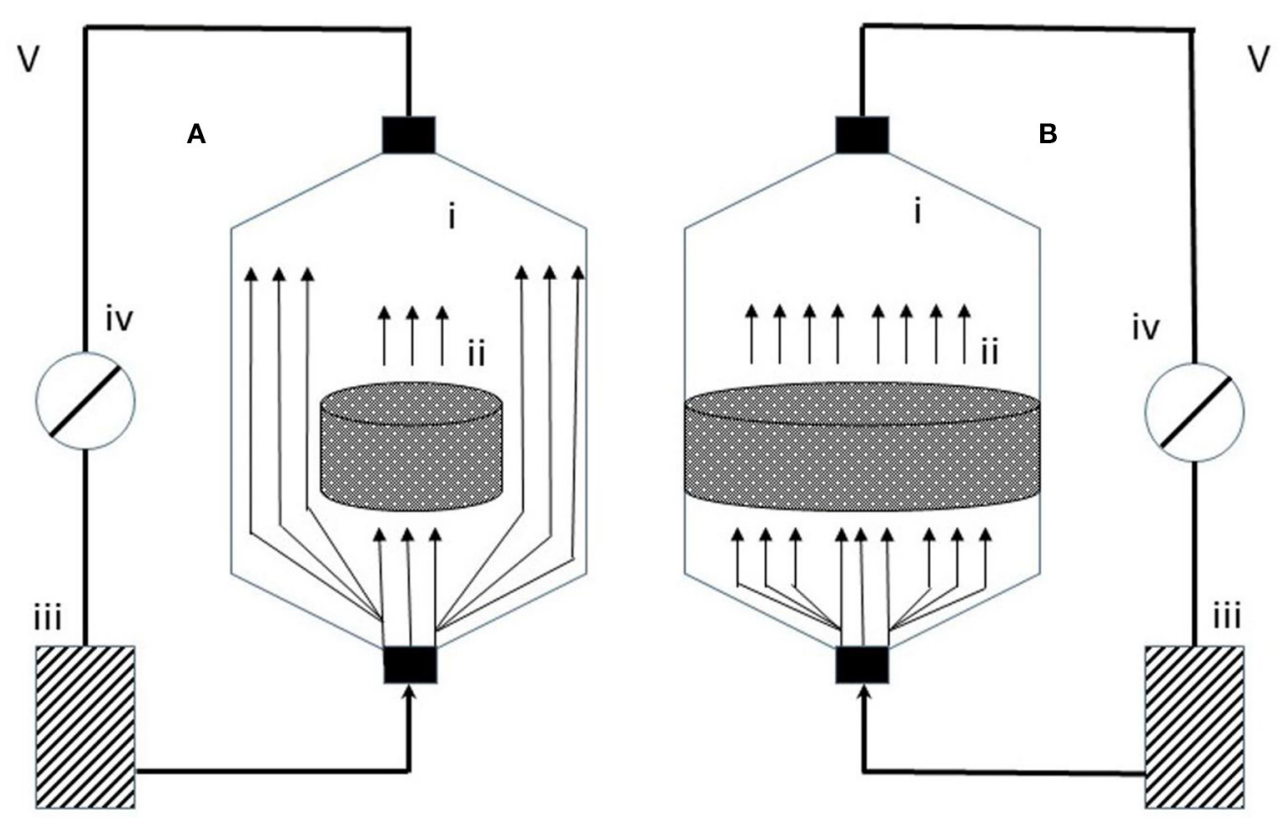

FIGURE 4 | Indirect (A) and direct (B) perfusion bioreactor [adapted after (29)] - a simple representation of indirect and direct perfusion bioreactors which are made of the culture chambers (i), the cell/scaffold constructs (ii), the culture medium reservoirs (iii), the peristaltic pumps (iv), and the tubing systems (v); The culture medium from indirect perfusion bioreactors has a specific characteristic because it follows the path of less resistance around the constructs. In direct perfusion bioreactors, the cell/scaffold is in a press-fitted fashion in the culture chamber; The medium is perfused throughout the constructs. 


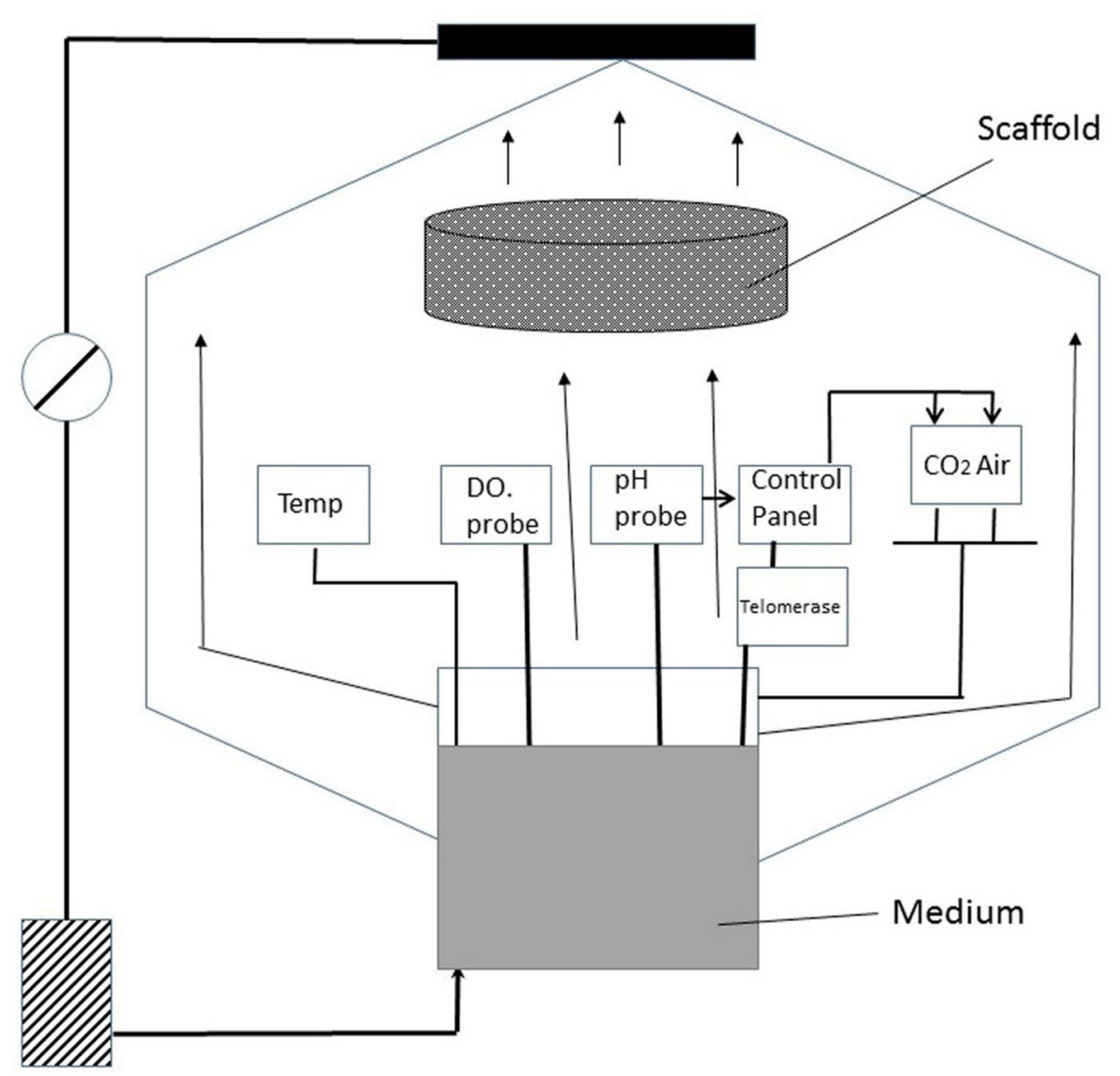

FIGURE 5 | Our proposal of bioreactor (original) is similar to a perfusion bioreactor with a small difference; This change is represented by the adding of telomerase to decrease the Hayflick limit; Regulating the expression or exogenous addition of telomerase can effectively enhance the potential for cell regeneration, which is conducive to large-scale, stable, and rapid proliferation of animal cells.

\section{ADVANTAGES/DISADVANTAGES OF CULTURED MEAT}

\section{The Impact of Cultured Meat on the Environment}

This paper focuses on providing a comprehensive perspective on the impact of cultured meat on the environment and human health. For instance, the impact of cultured meat on gas emissions: given that environmental pollution is increasing and global warming is a real threat, scientists suggest a sustainable solution to stop the industrialization processes that increases greenhouse gas emissions. Livestock farming is responsible for the production of the highest percentage of greenhouse gases in the atmosphere, especially methane and nitrogen oxide, and consequently for increasing the carbon footprint. This argument is very relevant in terms of herbivores, which produce in their rumen a lot of methane (greenhouse gas), due to their digestive process (61). Methane affects global warming 28 times more than carbon dioxide. Furthermore, nitrogen oxide from manure storage and fertilizer usage has a global warming potential 265 times higher than carbon dioxide (3). Tuomisto and Mattos (62) showed that cultivated meat production substantially reduces GHG emissions. The carbon footprint depends on the variation in the quantity and composition of emissions associated with contemporary in vitro meat production systems. $\mathrm{CH}_{4}$ and $\mathrm{N}_{2} \mathrm{O}$ emissions are relatively small and therefore do not significantly contribute to global warming dynamics. In the case of $\mathrm{CO}_{2}$, the continuous emission rate determines the long-term increase in heating (63).

As a result, cultured meat has a clear advantage over classical meat production, making it possible to control the working environment and the disposal of ancillary products.

United Nations Sustainable Developments Goals (SDGs) of the 2030 Agenda mention Climate Action as one of the important strategies to be considered. Production of cultured meat could significantly reduce gas emissions and therefore contribute to the decrease of green-house effects (64).

Greenhouse gas emissions such as $\mathrm{CO}, \mathrm{CO}_{2}, \mathrm{NOx}, \mathrm{CH}_{4}$, etc. can be captured using specially designed filters and devices (65). Furthermore, the energy used for the production of grown meat is lower compared to the one used for conventional beef and sheep, but higher compared to the energy used for swine and 


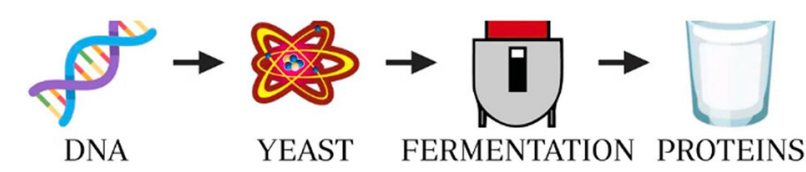

FIGURE 6 | Meat substitutes-acellular food production. Source: (57) First of all, acellular food production starts with a DNA sequence; Then it is inserted into yeast and makes fermentation, subsequently yielding new cells; The new cells are genetically identical to the mother cells.

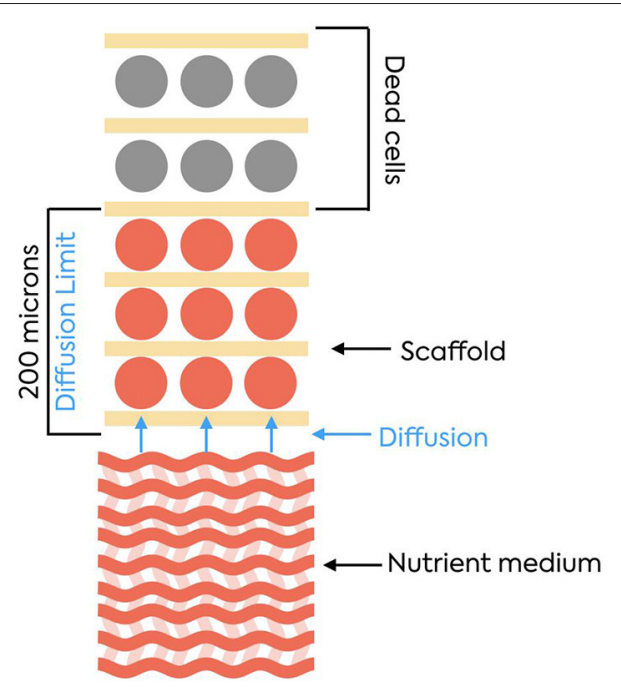

FIGURE 7 | Extracellular matrix. Source: (60) represents a structure that contains macromolecules, like collagens, enzymes, and glycoproteins; These help the cells grow by providing mechanical support; ECMs also have complex signaling molecules so the cells can communicate with one another.

poultry (8). These data are adequate for production equipment that uses a mixture of fuels of $43 \%$ natural gas, 33\% coal and $16 \%$ electricity, similar to the one used for obtaining malt beverages (66). It is somewhat normal because all other organs/tissues that can't be found in cultured meat production play an important role in ensuring the vital functions of the body, circulation, respiration, digestion and excretion. When it comes to cultivated meat, all these functions must be performed using energy.

Therefore, everything depends on the type of bioreactor used. According to Edelman et al. (67), on a large scale, the production of cultured meat requires the design of new bioreactors to maintain low shear as well as a large, uniformly infused volume. There are research studies of skeletal muscle tissue engineering that used NASA rotating bioreactors. The benefit of these bioreactors is that the cells are in almost continuous suspension, the shear of the fluid is minimal, and the suspension is possible for tissue assembly that is up to $1 \mathrm{~cm}$ (11). As a result, on a small scale, the biological notions of cultured meat production are relatively well-understood and developed, but the technology of large-scale production of cultured meat remains at an early stage. In this regard, changes have occurred over time with cell source, scaffold, culture media and bioprocessing $(11,55,67)$. In addition, one problem that is possibly associated with cultured meat is muscle atrophy, namely muscular loss due to cell size reduction (68) caused by lack of use, denervation or a variety of diseases $(69,70)$. In order to fix this problem, Edelman et al. (67) proposed a mechanical extension of the scaffold and of the extendable pearls for the scaffold in order to meet the requirements for ensuring contraction. Moreover, according to De Deyne (71), electrical stimulation can be performed on a large scale in order to induce internal contraction and serves to differentiate and form sarcomeres. Therefore, there are solutions to this possible problem.

\section{Impact of Cultured Meat on the Land Usage and Climate Change}

The surface of the land and the amount of water used for this are much smaller compared to those used for conventional meat (62). Thus, 70\% of all arable land on the planet represents the entire area required for animal husbandry (grazing land and feed production) (72). Production of cultured meat could reduce the need for arable land, thus natural habitats in various parts of the world could be restored, as stated by the United Nations Sustainable Developments Goals (SDGs) of the 2030 Agenda (Life on Land objective) (64).

\section{Impact of Cultured Meat on Water Pollution}

Through cultured meat production, both water usage and water pollution are considerably decreased compared to what conventional agriculture produces (62), because the zootechnical section uses water for feed production, animal husbandry and sewage. About $33 \%$ of the global pollution with nitrogen and phosphorus is due to the water used for stables. Moreover, this water represents half of the antibiotic pollution and contains more than $30 \%$ of the toxic heavy metals that contaminate fresh water (72).

\section{Impact of Cultured Meat on Animal Welfare}

In the scientific world, consensus has been reached on the health of animals and their ability to suffer, which is officially to be found in the EU animal welfare legislation $(73,74)$. Studies show that conscious experience is possible not only in the human brain, but also in animals $(75,76)$. Therefore, it is advisable to stop the suffering of animals under human care. Even if the EU has guidelines for ensuring animal welfare, it is specified that thorough animal health inspections should take place at proper intervals in order to avoid unnecessary suffering and in the case of animals raised on factory farms, at least once a day. However, these rules are often disregarded. In addition, the suffering caused by collecting stem cells from animals is negligible compared to that of animals in the conventional meat industry. Stem cell collection is performed under local or complete anesthesia, it does not take more than a few minutes and involves the use of a biopsy syringe and presents a low risk of long-term complications (77). According to Hopkins and Dacey (78) in vitro meat has the potential to reduce animal suffering considerably. Interestingly, the culture medium for cultured meat is represented by a sterile liquid that contains both essential macronutrients (sugars, amino acids) and micro-nutrients (vitamins, minerals). Currently, fetal 
bovine serum (FBS) is a key component of the standard culture medium used in biotechnology laboratories worldwide (79). Unfortunately, this is taken by sacrificing a pregnant cow and draining the blood from the fetus's heart, which obviously has not been anesthetized (Figure 8). This inhuman process is a major ethical issue against cultured meat (80).

Many researchers believe that ideal culture media should be free of nutrients from animals (80). In addition, culture media based on plants, fungus and microalgae have already been proven to work, which is why they should be used exclusively.

\section{Impact of Cultured Meat on Human Health}

Cultured meat can have beneficial effects on health, because it ensures control over the composition and quality of the meat. It can change the flavor, fat content and, in particular, the ratio between saturated and unsaturated fatty acids (11). Based on the fact that culture meat only includes muscle, it will not contain hormones and microorganisms that can endanger human life (such as Salmonella). Hormones are usually used to accelerate the growth of animals in order to increase the production of meat and seafood. Also, in vitro meat will be free of dioxins, antibiotics etc., which are usually found in conventional meat (4). Cell agriculture may lower the incidence of obesity and cardiovascular disease and significantly reduce the number of cases with foodborne illnesses, as well as reduce the incidence of animal-transmitted diseases $(8,11)$. Edwards $(81)$ reported that $60 \%$ of human diseases and $75 \%$ of emerging human diseases come from animal transmission. Thus, in humans, swine and avian influenza are transmitted from animals (82). Botulism becomes also a preventable disease by using controlled cellular agriculture.

It has been reported by cultured meat producers that antibiotics are not used during the process, as opposed to conventional agriculture, where antibiotics are widely used in sub-therapeutic doses to help animal tissue growth. The widespread use of antibiotics in animals has led to human growth of significant pathogen-resistant strains (83). The World Health Organization considers antibiotic resistance to be one of the biggest threats to global health (84). Therefore, the concept of One Health has lately emerged, which refers to the link between environmental, animal and human health. Production and consumption of cultured meat could represent a feasible solution that would allow avoiding the transmission of antibiotic resistance in this life circle. Classical meat production sometimes involves the use of various antibiotic substances. They may be administered in an inappropriate way, considering the dose, duration of treatment and complying with the specific withdrawal period of each antimicrobial. Therefore, antibiotic residues are often found in meat from slaughtered animals and are consumed by humans, leading to allergic reactions as well as acquisition of resistance. Researchers from Michigan State University claim that due to the high number of factors that contribute to its development, antibiotic resistance is a polarizing topic that has led to numerous disputes between the scientific and industrial worlds (85). Such experts believe that one priority should be raising awareness and ultimately finding alternative strategies (Figure 9) (86).

However, what happens in the case of senescence? In vitro meat production systems that use satellite cells still bring up questions about senescence. These can be resolved either by replacing them with fresh cells whenever needed, or by immortalizing the cell culture, which is achieved most easily by using embryonic stem cell cultures. As for fresh satellite cells, they can be extracted non-invasively, to start new cell cultures (70). The latter solution involves genetic changes of the cultured cells in such a way that senescence can be overcome by altering the ectopic expression of the telomerase enzyme gene (87). This method, which pertains to the field of genetic modification, could make consumers refuse them. The last possibility involves embryonic stem cells that are pluripotent and, apparently, have a limited ability to divide (88), therefore, the culture of embryonic stem cells derived from a single donor can be used infinitely in theory. However, embryonic stem cells need to differentiate into muscle cells before they can be used.

In 2015, Consumer Reports conducted a study that showed that out of approximately 500 kilograms of beef bought by chance in several cities in the United States, $100 \%$ contained bacteria with fecal contamination. As for cellular agriculture, which has no meat from livestock (where the highest contamination occurs), there is no risk of fecal contamination (89). Even though cultured meat may have a completely different risk profile from conventional meat, special attention should be paid to the safety of the added substrates and other compounds of the culture medium.

Therefore, there are fewer risks for microbial contamination, but more risks for substrate contamination (11). For individuals with sciatica or other iron deficiency diseases, who choose to be vegetarian/vegan, cultured meat can be an alternative to cure iron deficiency (90). Also, compared to conventional meat production, cultured meat is devoid of hormones. Such hormones are used to accelerate the growth of animals in order to increase the production of meat and seafood. Also, as it is known, about eight million tons of plastic materials get into the ocean every year (91). Given that microplastics are linked to chemicals used in manufacturing, more and more reports on their physical and chemical toxicity have started to appear as they are ingested by many species of fish and shellish. In vitro meat can reduce the pollution and toxicity caused by them. Also, by using cellular agriculture it is possible to avoid the contamination with residues in vegetable farms, too, when these are close to animal farms.

Another important issue regarding the use of cultured meat refers to the compliance with the United Nations Sustainable Developments Goals (SDGs) of the 2030 Agenda. The production and consumption of cultured meat could represent a sustainable solution to decrease of poverty and hunger. It is well-known that third world countries have an acute need for animal protein which could be replaced by cultured meat, if only it could be produced on a large scale and low cost. Also, good health and well-being could be improved by the consumption of cultured meat. It represents a healthier and non-contaminated source of nutrients, which can even be enriched by adding various 


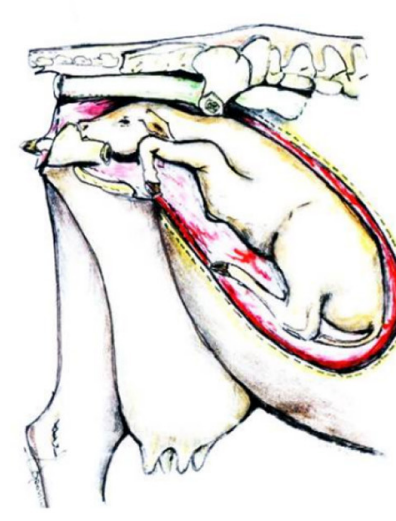

removal of uterus from pregnant cow
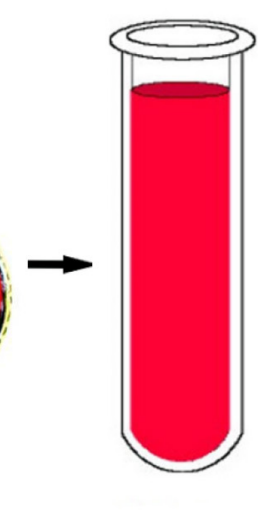

blood clotting

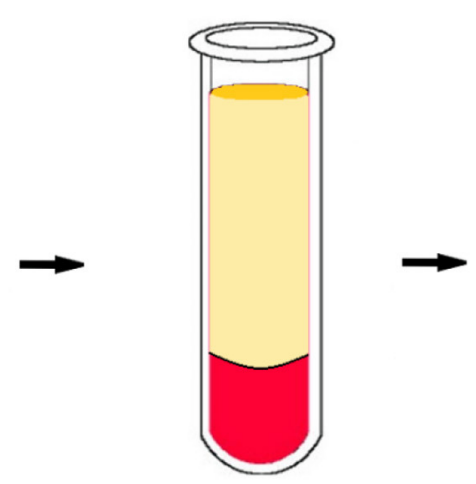

centrifuged blood

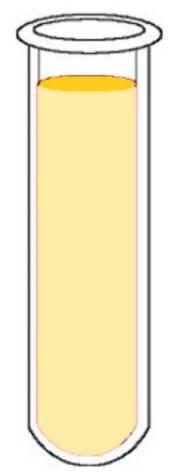

filtrated fetal calf serum (FCS)

FIGURE 8 | The obtaining of fetal bovine serum (original) this is taken by sacrificing a pregnant cow and draining the blood from the fetus's heart, which obviously has not been anesthetized.

other micronutrients which are missing from the diet in some geographical areas (64).

\section{Impact of Cultured Meat During Global Pandemic}

Government measures on travel restrictions have created a scarcity in various economic sectors, including agriculture (92). However, with various restrictions and growing health problems, the demand for organic and local foods has increased significantly. Regional and local agricultural products are more sold compared to other products (93).

Although it is not known that SARS-CoV-2 can be transmitted through food and this has been explicitly emphasized by authorities such as the European Food Safety Authority (94), a decrease of meat consumption was reported during the pandemic compared to other years. Moreover, according to the United Nations Biennial Report on the World Food Outlook, meat consumption per capita in 2020 recorded the highest decline since 2000. According to Steinberg et al. (95), this may be the result of market disruptions caused by outbreaks of infection among workers in the meat industry and related closures or reduced operation of meat processing facilities. In addition, another factor that contributes to this phenomenon was generated by the closure of schools and restaurants imposed in response to the COVID-19 pandemic (96). Moreover, it is possible that the hypothesis that meat production and consumption increase health risks in terms of infectious diseases may be responsible for the dietary choices of some individuals (97). However, there are studies that have reported a general increase, lack of a significant decrease in meat consumption during nationwide blockages imposed in a number of countries (98).

\section{The Quality of Cultured Meat}

The taste of real meat is influenced by the post mortem processing conditions, such as storage conditions, and preslaughter animal conditioning designed to preserve desirable meat quality. It is important to mention the fact that the metabolic transformation after death is represented by tissue hypoxia. The result is a decrease in intracellular $\mathrm{pH}$ (99). Moreover, acidic $\mathrm{pH}$ is responsible for losing water-binding capacity. As we expected, there are no studies regarding the quality of post-mortem metabolism of cultured meat, and basic studies to assess this process compare to animal-based meat are required given its significant contribution to meat properties (100).

Moreover, we are left with some questions, namely the nutrition value of cultured meat, because the taste, the texture is related to the nutritional specificity of the animals. In addition, if the animal has more intense physical activity, the meat is much richer in protein and low in fat. Also, the distribution of the type I or type II muscle fibers depends on the physical activity that certain subjects perform. This transition can be produced in the presence of B3 Vitamin (101). Probably in the function of the requirements, cultured meat producers have to adjust their products. Obviously, as is already known between these fibers, there are a number of metabolic differences, including those related to the metabolism of iron. The question is how culture meat can mimic these characteristics? Moreover, there are some compounds that are synthesized by endogenous cells but need exogenous supplementation. For example, as we have known the fats are responsible for the enhancer of good flavor for meats. Through oxidation, fatty acids can produce carbonyl compounds that are potent flavor contributors. Volatile compounds released from fat may be responsible for the species-specific flavors of beef, pork, and lamb (102). So, from this point of view, some fatty acids such as linoleic acid (103) and docosahexaenoic acid are synthesized through specific biohydrogenation from 


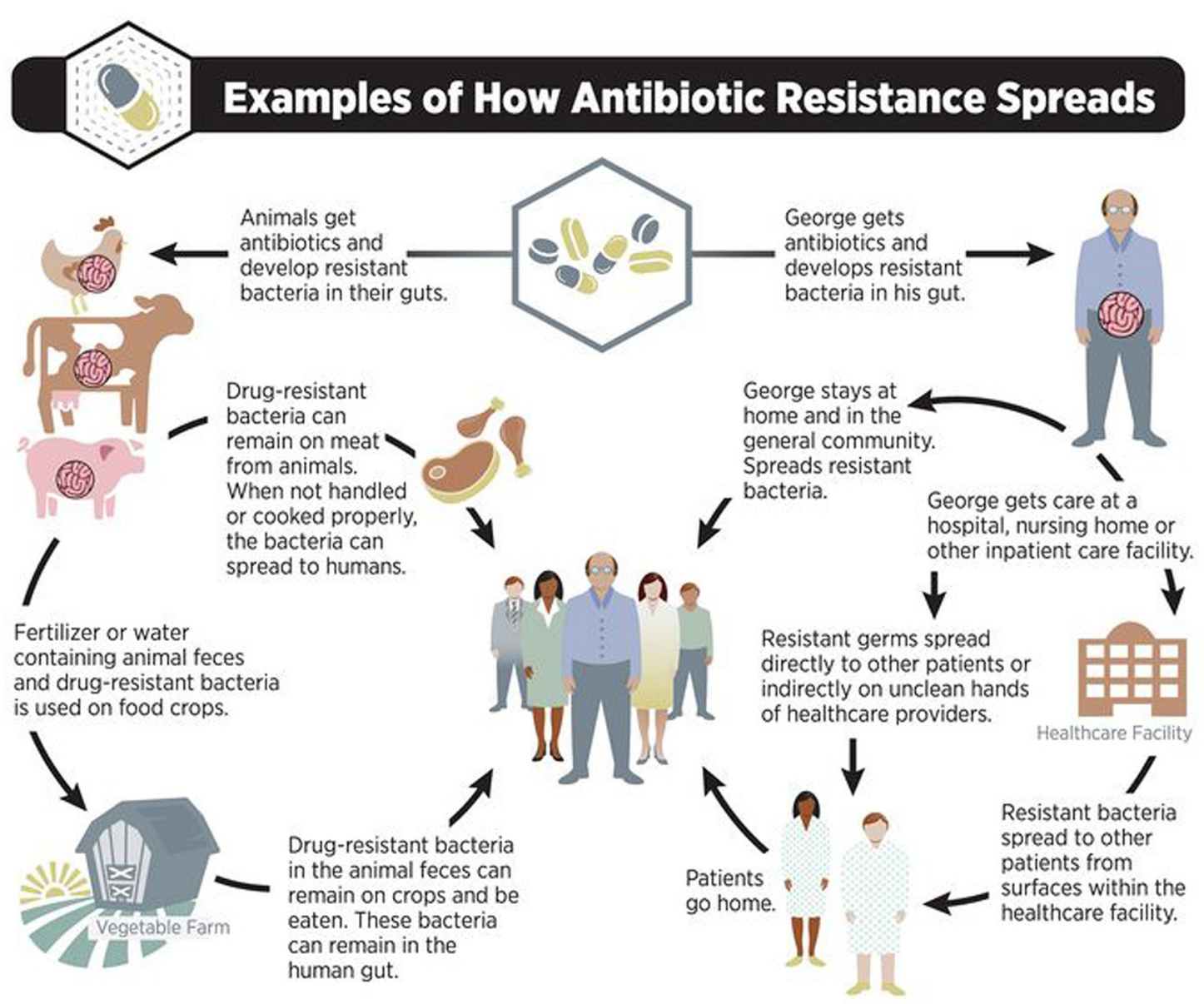

Simply using antibiotics creates resistance. These drugs should only be used to treat infections.

FIGURE 9 | Antibiotic Resistance Spreads. Source: (86). The large use of antibiotics represents the most important factor leading to world antibiotic resistance; For prevention, control, and treatment of disease, and also to promote growth they are commonly used in food-producing animals; For the treatment of plant crops against bacterial infections antibiotics are used in very small amounts.

the ruminant gut or algae, not by cultured adipocytes (104). In addition, there are some vitamins like B12 (105) that are microbial-derived. Choosing a healthier diet which nowadays represents a dominant trend around the consumers is vital for meats producers to introduce healthy acids in their meat (106).

\section{FUTURE TRENDS}

Conventional agriculture is linked to several problems, such as the environmental ones, due to the increase of greenhouse gas emission, pollution of the land surface used in industrialization, with a hint toward carbon footprint and global warming. From this point of view, we propose the calculation of the bioprocess efficiency and according to its adaptation in order to obtain a large-scale production with the lowest possible costs and a minimum degree of pollution. The organoleptic properties of cultured meat should perfectly mimic conventional meat in order to reach the consumer directly.
Animal welfare issues need to be taken seriously. Certain aspects related to the impact of this type of agriculture on human health should not be neglected, such as the source of infectious diseases, antibiotics resistance, products with low nutritional value. Also, we recommend improving the culture meat with micronutrients to avoid some pathologies.

In this context, alternative solutions should be found, analyzed and verified, in order to find out if they are sustainable. Cultured meat may represent such an alternative, but as it was mentioned, it is in its infancy and for the time being, it cannot be performed on a large scale. For potential effects to turn into results, a realistic understanding of the technology involved and more experimental studies are required.

Future studies should be performed taking into consideration the use of novel bioreactor types. New technical solutions should represent an objective of such studies in order to facilitate large scale-production of cultured meat. Moreover, the effect of cultured meat consumption on human health should be assessed, 
as well as antibiotic resistance, correlated with the One Health objective. Another important goal is to study the impact of cultured meat production on the environment and the feasibility of such production from an ecological perspective. These proposals must comply with the United Nation's Development Goals (SDGs) of the 2030 agenda. Out of the 17 objectives proposed by this strategy, cultured meat production could contribute and bring some benefits to the following: zero hunger, good health and well-being, climate action and life on land (64).

\section{REFERENCES}

1. United Nations, Department of Economic and Social Affairs, Population Division. World Population Prospects: The 2017 Revision, Key Findings and Advance Tables. (2017). Available online at: Working Paper No. ESA/P/WP/248. https://population.un.org/wpp/publications/files/ wpp2017_keyfindings.pdf (accessed August 15, 2020).

2. Alexander P, Brown C, Arneth A, Dias C, Finnigan J, Moran D, et al. Could consumption of insects, cultured meat or imitation meat reduces global agricultural land use? Glob Food Secur. (2017) 15:2232. doi: 10.1016/j.gfs.2017.04.001

3. Grossi G, Goglio A, Vitali A, Williams A. Livestock and climate change: impact of livestock on climate and mitigation strategies. Anim Front. (2019) 9:69-76. doi: 10.1093/af/vfy034

4. Arshad MS, Javaed M, Sohaib M, Saeed F, Imran A, Amjad Z. Tissue engineering approaches to develop cultured meat from cells: A mini review. Cogent Food Agric. (2017) 3:1320814. doi: 10.1080/23311932.2017.13 20814

5. Post, MJ. Cultured meat from stem cells: Challenges and prospects. Meat Sci. (2012) 92:297-301. doi: 10.1016/j.meatsci.2012.04.008

6. Assessing the Environmental Impacts of Consumption and Production: Priority Products and Materials. (2010). Available online at: https://www. resourcepanel.org/reports/assessing-environmental-impacts-consumptionand-production 2010. UNEP (accessed December 12, 2020).

7. Josson E, Linne T, Mccrow-Young, A. Many meats and many milks? The ontological politics of a proposed post-animal revolution. Sci Cult. (2019) 28:70-97. doi: 10.1080/09505431.2018.1544232

8. Mattick CS. Cellular agriculture: The coming revolution in food production. Bull At Sci. (2018) 74:32-35. doi: 10.1080/00963402.2017.1413059

9. Four Paws International. WHAT IS 'CULTIVATED MEAT'? (2020). Available online at: https://www.four-paws.org/campaigns-topics/topics/ nutrition/what-is-cultivated-meat (accessed January 12, 2021).

10. Martin I, Wendt D, Heberer M. The role of bioreactors in tissue engineering. Trends Biotechnol. (2004) 22:80-6. doi: 10.1016/j.tibtech.2003.12.001

11. Allan S, De Bank P, Ellis M. Bioprocess design considerations for cultured meat production with a focus on the expansion bioreactor. Front Sustain Food Syst. (2019) 3:44. doi: 10.3389/fsufs.2019.00044

12. Langer R, Vacanti JP. Tissue engineering. Science. (1993) 260:920-6.

13. Butler DL, Goldstein SA, Guilak F. Functional tissue engineering: the role of biomechanics. J Biomech Eng. (2000) 122:570-5. doi: 10.1115/1.1318906

14. Griffith LG, Naughton G. Tissue engineering - current challenges and expanding opportunities. Science. (2002) 295:100914. doi: $10.1126 /$ science. 1069210

15. Cukierman E, Pankov R, Stevens DR, Yamada KM. Taking cellmatrix adhesions to the third dimension. Science. (2001) 294:170812. doi: $10.1126 /$ science. 1064829

16. Freed LE, Langer R, Martin I, Pellis NR, Vunjak-Novakovic G. Tissue engineering of cartilage in space. Proc Natl Acad Sci USA. (1997) 94:1388590. doi: $10.1073 /$ pnas.94.25.13885

17. Holy CE, Shoichet MS, Davies JE. Engineering three-dimensional bone tissue in vitro using biodegradable scaffolds: investigating initial cellseeding density and culture period. J Biomed Mater Res. (2000) 51:37682. doi: 10.1002/1097-4636(20000905)

\section{AUTHOR CONTRIBUTIONS}

$\mathrm{CM}$, IG, and MC wrote the original draft and contributed substantially to the design of the research, to the collection, and interpretation of the data. VM, AI, CR, and PU determined a critical revision of the article and data curation. DP and AN contributed to the realization of the last version of the manuscript through conceptualization and investigation. All authors have read and agreed to the published version of the manuscript.

18. Vunjak-Novakovic G, Freed LE, Biron RJ, Langer R. Effects of mixing on the composition and morphology of tissue-engineered cartilage. AIChE Journal. (1996) 42:850-60.

19. Carrier RL, Papadaki M, Rupnick M, Schoen FJ, Bursac N, Langer R, et al. Cardiac tissue engineering: cell seeding, cultivation parameters, and tissue construct characterization. Biotechnol Bioeng. (1999) 64:5809. doi: 10.1002/(sici)1097-0290(19990905)

20. Kim BS, Putnam AJ, Kulik TJ, Mooney DJ. Optimizing seeding and culture methods to engineer smooth muscle tissue on biodegradable polymer matrices. Biotechnol Bioeng. (1998) 57:46-54.

21. Burg KJ, Delnomdedieu M, Beiler RJ, Culberson CR, Greene KG, Halberstadt $\mathrm{CR}$, et al. Application of magnetic resonance microscopy to tissue engineering: a polylactide model. J Biomed Mater Res. (2002) 61:38090. doi: 10.1002/jbm.10146

22. Wendt D, Marsano A, Jakob M, Heberer M, Martin I. Oscillating perfusion of cell suspensions through three-dimensional scaffolds enhances cell seeding efficiency and uniformity. Biotechnol Bioeng. (2003) 84:20514. doi: 10.1002/bit.10759

23. Vunjak-Novakovic G, Obradovic B, Martin I, Bursac PM, Langer R, Freed LE. Dynamic cell seeding of polymer scaffolds for cartilage tissue engineering. Biotechnol Prog. (1998) 14:193-202. doi: 10.1021/bp970120j

24. Li Y, Ma T, Kniss DA, Lasky LC, Yang ST. Effects of filtration seeding on cell density, spatial distribution, and proliferation in nonwoven fibrous matrices. Biotechnol Prog. (2001) 17:935-44. doi: 10.1021/bp0100878

25. Rauh J, Milan F, Günther KP, Stiehler M. Bioreactor systems for bone tissue engineering. Tissue Eng Part B Rev. (2011) 17:263-80. doi: 10.1089/ten.TEB.2010.0612 fig 2

26. Villalona GA, Udelsman B, Duncan DR, McGillicuddy E, Sawh-Martinez RF, Hibino N, et al. Cell-seeding techniques in vascular tissue engineering. Tissue Eng. (2010) 16:341-50. doi: 10.1089/ten.TEB.2009.0527

27. Li Y, Kniss DA, Lasky L C, Yang ST. Culturing and differentiation of murine embryonic stem cells in a three-dimensional fibrous matrix. Cytotechnology. (2003) 41: 23-35. doi: 10.1023/A:1024283521966

28. Blair HC, Larrouture QC, Li Y, Lin H, Beer-Stoltz D, Liu L, et al. Osteoblast differentiation and bone matrix formation in vivo and in vitro. Tissue Eng. (2017) 23:268-80. doi: 10.1089/ten.TEB.2016.0454

29. Sladkova M, Maria De Peppo G. Bioreactor systems for human bone tissue engineering. Processes. (2014) 22:494-525. doi: 10.3390/pr2020 494

30. Ahmed GM, Abouauf EA, AbuBakr N, Dörfer CE, El-Sayed KF. Tissue engineering approaches for enamel, dentin, and pulp regeneration: an update. Stem Cells Int. (2020) 2020:5734539. doi: 10.1155/2020/5734539

31. Santoro M, Lamhamedi-Cherradi SE, Menegaz BA, Ludwig JA, Mikos AG. Flow perfusion effects on three-dimensional culture and drug sensitivity of Ewing sarcoma. Proc Natl Acad Sci USA. (2015) 112:103049 doi: $10.1073 /$ pnas. 1506684112

32. Sodian R, Lemke T, Fritsche C, Hoerstrup SP, Fu P, Potapov EV, et al. Tissue-engineering bioreactors: a new combined cell-seeding and perfusion system for vascular tissue engineering. Tissue Eng. (2002) 8:86370. doi: 10.1089/10763270260424222

33. Davisson T, Sah RL, Ratcliffe A. Perfusion increases cell content and matrix synthesis in chondrocyte three-dimensional cultures. Tissue Eng. (2002) 8:807-16. doi: 10.1089/10763270260424169 
34. Radisic M, Euloth M, Yang L, Langer R, Freed LE, Vunjak-Novakovic G. High-density seeding of myocyte cells for cardiac tissue engineering. Biotechnol Bioeng. (2003) 82:403-14. doi: 10.1002/bit.10594

35. Bancroft GN, Sikavitsas VI, van den Dolder J, Sheffield TL, Ambrose CG, Jansen JA, et al. Fluid flow increases mineralized matrix deposition in $3 \mathrm{D}$ perfusion culture of marrow stromal osteoblasts in a dose-dependent manner. Proc Natl Acad Sci USA. (2002) 99:12600-5. doi: 10.1073/pnas.202296599

36. Navarro FA, Mizuno S, Huertas JC, Glowacki J, Orgill DP. Perfusion of medium improves growth of human oral neomucosal tissue constructs. Wound Repair Regen. (2001) 9:507-12. doi: 10.1046/j.1524-475x.2001.00507.x

37. Carrier RL, Rupnick M, Langer R, Schoen FJ, Freed LE, Vunjak-Novakovic G. Perfusion improves tissue architecture of engineered cardiac muscle. Tissue Eng. (2002) 8:175-88. doi: 10.1089/107632702753724950

38. Démarteau O, Wendt D, Braccini A, Jakob M, Schäfer D, Heberer M, et al. Dynamic compression of cartilage constructs engineered from expanded human articular chondrocytes. Biochem Biophys Res Commun. (2003) 310:580-8. doi: 10.1016/j.bbrc.2003.09.099

39. Bhat ZF, Morton JD, Mason SL, Bekhit AEA, Bhat HF. Technological, regulatory, and ethical aspects of in vitro meat: a future slaughterfree harvest. Comprehen Rev Food Sci Food Safety. (2019) 18:1192208. doi: 10.1111/1541-4337.12473

40. Bhat ZF, Bhat HF, Kumar S. Cultured meat-a humane meat production system. In: Lanza R, Langer R, Vacanti JP, Atala A, editors. Principles of Tissue Engineering, 5th Edition. London: Elsevier Publication (2020).

41. Bhat ZF, Bhat H. Tissue engineered meat-future meat. J Stored Prod Postharvest Res. (2011) 2:1-10. doi: 10.5897/JSPPR.9000047

42. Bhat ZF, Bhat HF, Pathak V. Prospects for in vitro cultured meat- a future harvest. In: Lanza R, Langer R, and Vacanti JP, editors. Principles of Tissue Engineering, 4th Edition. London: Elsevier Publication (2014).

43. Bonny SPF, Gardner GE, Pethick DW, Hocquette JF. What is artificial meat and what does it mean for the future of the meat industry? J Integr Agric. (2015) 14:255-63. doi: 10.1016/S2095-3119(14)60888-1

44. Chriki S, Hocquette JF. The myth of cultured meat: a review. Front Nutr. (2020) 7:7 doi: 10.3389/fnut.2020.00007

45. Bhat ZF, Fayaz H. Prospectus of cultured meat advancing meat alternatives. J Food Sci Technol. (2011) 48:125-40. doi: 10.1007/s13197-010-0198-7

46. Cravero D, Martignani E, Miretti S, Accornero P, Pauciullo A, Sharma R, et al. Generation of induced pluripotent stem cells from bovine epithelial cells and partial redirection toward a mammary phenotype in vitro. Cell Reprogram. (2015) 17:211-20. doi: 10.1089/cell.2014.0087

47. Zhao L, Wang Z, Zhang J, Yang J, Gao X, Wu B, et al. Characterization of the single-cell derived bovine induced pluripotent stem cells. Tissue Cell. (2017) 49:521-7. doi: 10.1016/j.tice

48. Masters JR, Stacey GN. Changing medium and passaging cell lines. Nat Protoc. (2007) 2:2276-84. doi: 10.1038/nprot.2007.319

49. Shay JW, Wright WE. Hayflick, his limit, and cellular ageing. Nat Rev Mol Cell Biol. (2000) 1:72-6. doi: 10.1038/35036093

50. Kleinert LB, Hoying JB, Williams SK. The neointima formed in endothelial cell sodded ePTFE vascular grafts results from both cellularhyperplasia and extracellular-hypertrophy. Cell Transplant. (1996) 5:47582. doi: 10.1016/0963-6897(96)00024-3

51. Wragg NM, Player DJ, Martin NRW, Liu Y, Lewis MP. Development of tissue-engineered skeletal muscle manufacturing variables. Biotechnol Bioeng. (2019) 116:2364-76. doi: 10.1002/bit.27074I

52. Fraeye I, Kratka M, Vandenburgh H, Thorrez L. Sensorial and Nutritional Aspects of Cultured Meat in Comparison to Traditional Meat: Much to Be Inferred. Frontiers in nutrition. (2020) 7:35 doi: 10.3389/fnut.2020. 00035

53. World's First Lab-Grown Burger Is Eaten in London. (2013). Available online at: http://www.bbc.com. BBC (accessed July 17, 2020).

54. Stephens N, Sexton A, Driessen C. Making sense of making meat: key moments in the first 20 years of tissue engineering muscle to make food. Front Sustain Food Syst. (2019) 3:45. doi: 10.3389/fsufs.2019.00045

55. Stephens N, Di Silvio L, Dunsford I, Ellis M, Glencross A, Sexton A. Bringing cultured meat to market: Technical, socio-political, and regulatory challenges in cellular agriculture. Trends Food Sci Tech. (2018) 78:15566. doi: 10.1016/j.tifs.2018.04.010

56. Hoek AC, Luning PA, Luning A, Stafleu A, Graaf C. Food-related lifestyle and health attitudes of Dutch vegetarians, non-vegetarian consumers of meat substitutes, and meat consumers. Appetite. (2004) 42:7. doi: 10.1016/j.appet.2003.12.003

57. Cell Based Tech (2019). Available online at: https://cellbasedtech.com/2019/ 01/acellular-production (accessed May 14, 2020).

58. Hocquette A, Lambert C, Sinquin C, Peterolff L, Wagner Z, Lebert A, et al. Educated consumers don't believe artificial meat is the solution to the problems with the meat industry. J Integr Agric. (2015) 14:27384. doi: 10.1016/S2095-3119(14)60886-8ff

59. Van der Weele C, Driessen C. Emerging profiles for cultured meat. Ethics through and as design. Animals. (2013) 3:647-62. doi: 10.3390/ani3030647

60. Labs are the New Farms (2019). Available online at: https://izzygrandic. medium.com/labs-are-the-new-farms-a-guide-to-alternative-proteinpart-1-3ed67462e8eb (accessed April 26, 2020).

61. Hocquette JF. Is in vitro meat the solution for the future? Meat Sci. (2016) 120:167-76. doi: 10.1016/j.meatsci.2016.04.036

62. Tuomisto HL, Teixeira de Mattos MJ. Environmental impacts of cultured meat production. Environ Sci Technol. (2011) 45:6117-23. doi: 10.1021/es200130u

63. Lynch J, Pierrehumbert R. Climate impacts of cultured meat and beef cattle. Front Sustain Food Syst. (2019) 3:5. doi: 10.3389/fsufs.2019.00005

64. United Nations Foundation (2015). Available online at: https:// unfoundation.org/what-we-do/issues/sustainable-development-goals (accessed August 23, 2021).

65. Lin Y, Kong C, Zhang Q, Chen L. Metal-organic frameworks for carbon dioxide capture and methane storage. Adv Energy Mater. (2016) 7:4. doi: 10.1002/aenm.201601296

66. Galitsky C, Martin N, Worrell E, Lehman, B. Energy efficiency improvement and cost saving opportunities for breweries: an ENERGY STAR(R) guide for energy and plant managers (2003). doi: 10.2172/819468

67. Edelman PD, McFarland DC, Mironov VA, Matheny JG. Commentary: vitro-cultured meat production. Tissue Eng. (2005) 11:659-62. doi: 10.1089/ten.2005.11.659

68. Fox SI. Human Physiology. Boston: Wim C. Brown (1996).

69. Charge S, Brack A, Hughes SM. Aging-related satellite cell differentiation defect occurs prematurely after Ski-induced muscle hypertrophy. Am J Physiol Cell Physiol. (2002) 283:C1228-41. doi: 10.1152/ajpcell.00206.2002

70. Ohira $Y$, Yoshinaga $T$, Nomura $T$, Kawano F, Ishihara A, Nonaka I, et al. Gravitational unloading effects on muscle fiber size, phenotype and myonuclear number. Adv Space Res. (2002) 30:777-81. doi: 10.1016/s0273-1177(02)00395-2

71. De Deyne PG. Formation of sarcomeres in developing myotubes: role of mechanical stretch and contractile activation. Am J Physiol Cell Physiol. (2000) 279:C1801-11. doi: 10.1152/ajpcell.2000.279.6.C1801

72. Livestock's long shadow: environmental issues and options (2006). Available online at. http://www.fao.org (accessed May 14, 2020).

73. Low J, Panksepp D, Reiss D, Edelman B, Swinderen V, Koch C. The Cambridge Declaration on Consciousness. Cambridge: University of Cambridge (2012).

74. Animal welfare (2009). Available online at: https://ec.europa.eu/food/ system/files/2016-10/aw_european_convention_protection_animals_en.pdf (accessed May 14, 2020).

75. Berridge KC, Kringelbach ML. Building a neuroscience of pleasure and wellbeing. Psychol Well Being. (2011) 1:1-3. doi: 10.1186/2211-1522-1-3

76. Griffin DR, Speck GB. New evidence of animal consciousness. Anim Cogn. (2004) 7:5-18. doi: 10.1007/s10071-003-020

77. Melzener L, Verzijden KE, Buijs AJ, Post MJ, Flack JE. Cultured beef: from small biopsy to substantial quantity. J Sci Food Agricult. (2021) 101:714. doi: $10.1002 /$ jsfa. 10663

78. Hopkins PD, Dacey A. Vegetarian meat: could technology save animals and satisfy meat eaters? J Agric Environ Ethics. (2008) 21:579-96. doi: 10.1007/s10806-008-9110-0

79. The meat revolution. (2015). Available online at: https://www.youtube.com (accessed December 12, 2020). 
80. Fujita H, Endo A, Nagamori E. Evaluation of serum-free differentiation conditions for $\mathrm{C} 2 \mathrm{C} 12$ myoblast cells assessed as to active tension generation capability. Biotechnol Bioeng. (2010) 107:894-901. doi: 10.1002/bit.22865

81. Edwards B. The Need to Transform How We Eat or, How I Learned to Stop Worrying and Love Vegetables. (2017). Available online at: https://alttext. com/the-need-to-transform-how-we-eat-or-d59d17e71902

82. De Vleeschauwer AD, Poucke SV, Braeckmans D, Doorsselaere JV, Reeth KV. Efficient transmission of swine-adapted but not wholly avian influenza viruses among pigs and from pigs to ferrets. J Infect Dis. (2009) 200:188492. doi: $10.1086 / 648475$

83. Landers TF, Cohen B, Wittum TE, Larson EL. A review of antibiotic use in food animals: perspective, policy, and potential. Public Health Rep. (2012) 127:4-22. doi: 10.1177/003335491212700103

84. Burbon T, Smith A, Savatier P. Signalling, cell cycle and pluripotency in embryonic stem cells. Trends Cell Biol. (2002) 12:432-8. doi: 10.1016/s0962-8924(02)02352-8

85. Cantas L, Shah SQ, Cavaco LM, Manaia CM, Walsh F, Popowska M, et al. A brief multi-disciplinary review on antimicrobial resistance in medicine and its linkage to the global environmental microbiota. Front Microbiol. (2013) 4:96. doi: 10.3389/fmicb.2013.00096

86. World Health Organization. 10 Threats to Global Health in 2018. (2018). Available online at: https://medium.com/@who/10-threats-toglobal-healthin-2018-232daf0bbef3 (accessed December 12, 2020).

87. Alberts B, Bray D. Molecular Biology of the Cell. 3rd ed. New York, NY: Garland Science. (1994)

88. Warning issued over 50 years ago still rings true: CDC renews attention to antibiotic resistance (2014). Available online at: https://www.canr.msu.edu/ news/cdc_report_brings_renewed_attention_to_seriousness_of_antibiotic_ resistance (accessed December 12, 2020)

89. Reese J. The End of Animal Farming: How Scientists, Entrepreneurs, and Activists Are Building an Animal-Free Food System. Publisher: Beacon Press (2018).

90. Gasteratos K. 90 Reasons to Consider Cellular Agriculture. (2019). Available online at: https://dash.harvard.edu/handle/1/38573490 (accessed December 12, 2020).

91. Global plastic production rises recycling lags. Vital Signs. (2015). Available online at: http://www.plastic-resource-center.com/wp-content/uploads/ 2018/11/Global-Plastic-Production-RisesRecycling-Lags.pdf (accessed November 15, 2020).

92. Kalogiannidis S, Melfou K. Issues and opportunities for agriculture sector during global pandemic. Int J Econ Business Manage Res. (2020) 12:204-11. Available online at: http://www.ijebmr.com/uploads/pdf/archivepdf/2020/ IJEBMR_659.pdf

93. Rowan NJ, Galanakis CM. Unlocking challenges and opportunities presented by COVID-19 pandemic for cross-cutting disruption in agri-food and green deal innovations: Quo Vadis? Sci Total Environ. (2020) 748:141362. doi: $10.1016 /$ j.scitotenv. 141362

94. Coronavirus: no evidence that food is a source or transmission route. (2021). Available online at: https://www.efsa.europa.eu/en/news/coronavirus-noevidence-food-source-or-transmission-route (accessed January 15, 2021).

95. Steinberg J, Kennedy ED, Basler C, Grant MP, Jacobs JR, Ortbahn D, et al. COVID-19 outbreak among employees at a meat processing facility - South Dakota. MMWR Morb Mortal Wkly Rep. (2020) 69:10159. doi: 10.15585/mmwr.mm6931a2
96. Attwood S, Hajat C. How will the COVID-19 pandemic shape the future of meat consumption? Public Health Nutr. (2020) 23:311620. doi: 10.1017/S136898002000316X

97. Abd-Alrazaq A, Alhuwail D, Househ M, Hamdi M, Shah Z. Top concerns of tweeters during the COVID-19 pandemic: infoveillance study. J Med Internet Res. (2020) 22:e19016. doi: 10.2196/19016

98. Górnicka M, Drywień ME, Zielinska MA, Hamułka J. Dietary and lifestyle changes during COVID-19 and the subsequent lockdowns among Polish adults: a cross-sectional online survey PLifeCOVID-19 study. Nutrients. (2020) 12:2324. doi: 10.3390/nu12082324

99. Matarneh SK, England EM, Scheffler TL, Gerrard DE. The Conversion of Muscle to Meat, Lawrie's Meat Sci. 8th edition. Duxford: Woodhead Publishing, Elsevier (2017).

100. Shengyong $\mathrm{Ng}$, Kurisawa M. Integrating biomaterials and food biopolymers for cultured meat production. Acta Biomater. (2021) 124:108-29. doi: 10.1016/j.actbio.2021.01.017

101. Khan M, Couturier A, Kubens JF, Most E, Mooren FC, Krüger K, et al. Niacin supplementation induces type II to type I muscle fiber transition in skeletal muscle of sheep. Acta Vet Scand. (2013) 55:85. doi: 10.1186/1751-014 7-55-85

102. Savell JW, Cross HR. The role of fat in the palatability of beef, pork, and lamb. In: Designing Foods; Animal Product Options in the Market Place. Washington, DC: National Academy Press (1988).

103. Wood JD, Enser M, Fisher AV, Nute GR, Sheard PR, Richardson RI, et al. Fat deposition, fatty acid composition and meat quality: a review. Meat Sci. (2008) 78:343-58. doi: 10.1016/j.meatsci.2007.07.019

104. Bradbury J. Docosahexaenoic acid (DHA): an ancient nutrient for the modern human brain. Nutrients. (2011) 3:529-54. doi: 10.3390/nu3050529

105. Obeid R, Heil SG, Verhoeven MMA, van den Heuvel EGHM, de Groot LCPGM, Eussen SJPM. Vitamin B12 intake from animal foods, biomarkers, and health aspects. Front Nutr. (2019) 6:93. doi: 10.3389/fnut.2019.00093

106. Jimenez-Colmenero F, Salcedo-Sandoval L, Bou R, Cofrades S, Herrero AM Ruiz-Capillas C. Novel applications of oil-structuring methods as a strategy to improve the fat content of meat products. Trends Food Sci Technol. (2015) 44:177-88. doi: 10.1016/j.tifs.2015.04.011

Conflict of Interest: The authors declare that the research was conducted in the absence of any commercial or financial relationships that could be construed as a potential conflict of interest.

Publisher's Note: All claims expressed in this article are solely those of the authors and do not necessarily represent those of their affiliated organizations, or those of the publisher, the editors and the reviewers. Any product that may be evaluated in this article, or claim that may be made by its manufacturer, is not guaranteed or endorsed by the publisher.

Copyright (c) 2021 Munteanu, Mireşan, Răducu, Ihuţ, Uiuiu, Pop, Neacşu, Cenariu and Groza. This is an open-access article distributed under the terms of the Creative Commons Attribution License (CC BY). The use, distribution or reproduction in other forums is permitted, provided the original author(s) and the copyright owner(s) are credited and that the original publication in this journal is cited, in accordance with accepted academic practice. No use, distribution or reproduction is permitted which does not comply with these terms. 